animal and producing the condition, thus solving an age-old problem. The experimental work on the elucidation of the nature of rickets and scurvy as being due to vitamin deficiency, on the discovery of drugs curative for streptococcal infections, such as puerperal fever and pneumonia, and on the nature of cancer, were described. Finally, Sir Edward pointed out both the importance and the limits of clinical observation, and discussed some of the criticisms and failures of the experimental method.

\section{Early Cultural Relations in Central America}

Arova communications dealing with the archæology of Central America presented to the Twentyseventh International Congress of Americanists, which met in Mexico City on August 5-15 (see NAtURE, Aug. 19, p. 319), there were several, it would appear from a preliminary report issued by Science Service of Washington, which brought forward suggestions and advanced conclusions of considerable interest in reference to the cultural relations of, and cultural successions among, the early inhabitants of Mexico and the adjacent regions. Dr. Alfonso Caso, president of the Congress, for example, in describing the results of his excavations on Monte Alban, not only argued for the common origin of the culture of that site with that of the not far distant ruined city of Mitla on the evidence of architectural affinitics, but also put forward the conclusion that three stages of development are to be distinguished, which can be linked respectively with the Archaic culture of Mexico, dating from before the Christian era, the Toltec of Teotihuacan, and the Aztec. Further, Dr. A. V. Kidder, reporting on his excavations in pit-tombs near Guatemala city, assigns their builders to a period corresponding with the middle period at Monte Alban, or when the great Toltec civilization of central Mexico was approaching its decline. It would appear that the pottery from the Guatemalan pit-tombs provides a key which links the tomb builders with other early cultures of tropical central America. Some light was also thrown on the development of agriculture among the early peoples by Dr. Pablo Martínez del Rio, who advanced the theory that agriculture may have had a more rapid rise in the New World than in the Old, on the ground that differences in methods of seed selection and cultivation speeded up results for the Indian farmer, so that it was not necessary to postulate, as some botanists have done, an extremely long period of development.

\section{Electrical Development in Iraq}

IN a paper communicated to the Electrical Review of August 18 by W. H. Peters of Baghdad, a review is given of the post-War development of Iraq. Both Bughdad, the capital city, and Basra, its modern seaport, were left electricity systems installed by the British Army during the occupation. Being war products, they were limited in capacity and of antiquated design. During the past fifteen years these supply undertakings have been transferred to concessionaries or to the Government. The most provincial of the centre towns have shown initiative in the promotion of schemes for small plants primarily to serve the requirements of the administrative authorities for fans and for street lighting. The largest supply undertaking is that in the capital city, Baghdad, the population of which is about 250,000 . It is directed by the Baghdad Light and Power Co., which is registered in the United Kingdom. It is the only supply station left which is of foreign ownership. The main thoroughfares of the city are copiously lighted, the load exceeding 300,000 watts. The port of Basra set up an efficient power station five years ago and the sale of energy in the port and the municipal area which it supplies has exceeded all expectations. The rate at which it sells power is $4 \frac{1}{2} d$. per unit for lighting and $2 \frac{1}{2} d$. per unit for domestic power.

WIthis a year the 'Iragi State Railway will be finally completed to tho northern city of Mosul and will permit of railroad goods traffic both westwards to Syria and southwards to Basra passing en route Basra, Baghdad, Syria, Turkey and so on to Europe. This great need once fulfilled is almost certain to develop the import and export trade of Mosul, thereby increasing its prosperity. Until three years ago all the Diesel power stations were run by plant entirely of British origin, but recently German plant has mado considerable headway. Iraq's exports of oil and agricultural progress show a very satisfactory increase year by year and these contribute to increased national wealth and a higher standard of living. This increase in the standard of living is not confined to the property owners and married classes, but is apparent almost everywhere. It is noteworthy that Britain has hitherto enjoyed no commercial privileges in Iraq.

\section{Coal Utilization by Electricity}

Accordina to the Electrical Review of September 1, MIr. MI. Anderson, the director of the Coal Utilisation Council, estimated that to keep the public properly warm would necessitate the consumption of eight million more tons of coal per annum. To raise the standard of 'heat comfort' was one of the principal aims of the plan of campaign outlined at the last National Coal Convention. Since the success of the campaign would depend largely upon the development of the domestic and industrial demand for electric power and especially that used for 'space heating', convenience rather than necessity would be the controlling influence in regulating the demand for coal for power. MIr. Anderson referred to several other methods of increasing the coal output to com. pensate for the falling off in the direct demand for coal owing to the increasing use of electric power and heating in many trades. Trolley buses, also, although they have greatly diminished the demand for electric tramways and in spite of the competition of oil-engine buses, have probably increased the total demand for electric power from the public mains and consequently for coal. Trolley-buses move faster and give a much better service than almost any other 